Original Article

\title{
COMPARATIVE STUDY OF THE ANTINOCICEPTIVE ACTION OF AMITRIPTYLINE WITH FLUOXETINE AND EVALUATION OF THEIR PROBABLE MECHANISM OF THIS ACTION IN ALBINO MICE
}

\author{
PHULEN SARMA ${ }^{*}$, DAISY PHUKAN ${ }^{2}$ \\ ${ }^{1}$ MD Pharmacology Resident, ${ }^{2}$ Associate Professor, Department of Pharmacology, Assam Medical College and Hospital \\ Email: phulen10@gmail.com
}

Received: 03 Jun 2018 Revised and Accepted: 26 Sep 2018

\begin{abstract}
Objective: The aim of our study was to compare the anti-nociceptive action of amitriptyline with fluoxetine and evaluation of their probable mechanism of anti-nociceptive action by observing their individual interactions with morphine, naloxone, yohimbine, and ondansetron.

Methods: Albino mice weighing 25-35 grams were taken and divided into 12 groups. Group A-Control(distilled water), Group B-amitriptyline 20 $\mathrm{mg} / \mathrm{kg}$, Group C-fluoxetine $20 \mathrm{mg} / \mathrm{kg}$, Group D-morphine $5 \mathrm{mg} / \mathrm{kg}$, Group E-amitriptyline $20 \mathrm{mg} / \mathrm{kg}+$ morphine $5 \mathrm{mg} / \mathrm{kg}$, Group F-amitriptyline 20 $\mathrm{mg} / \mathrm{kg}+$ naloxone $3 \mathrm{mg} / \mathrm{kg}$, Group G-amitriptyline $20 \mathrm{mg} / \mathrm{kg}+$ yohimbine $2 \mathrm{mg} / \mathrm{kg}$, Group H-amitriptyline $20 \mathrm{mg} / \mathrm{kg}+$ ondansetron 0.1 mg/kg, Group Ifluoxetine $20 \mathrm{mg} / \mathrm{kg}+$ morphine $5 \mathrm{mg} / \mathrm{kg}$, Group J-fluoxetine $20 \mathrm{mg} / \mathrm{kg}+$ naloxone $3 \mathrm{mg} / \mathrm{kg}$, Group K-fluoxetine $20 \mathrm{mg} / \mathrm{kg}+$ yohimbine $2 \mathrm{mg} / \mathrm{kg}$ and Group L-fluoxetine $20 \mathrm{mg} / \mathrm{kg}+$ ondansetron $0.1 \mathrm{mg} / \mathrm{kg}$. Hot plate method and acetic acid writhing test were used to assess central and peripheral analgesic activity respectively.

Results: Both the amitriptyline and fluoxetine-treated animals showed significantly increased reaction time in a hot plate ( $<<0.05$ ) and a significant decrease in the number of wriths in acetic acid writhing test $(\mathrm{p}<0.05)$, when compared with control. Animals in amitriptyline group showed significantly higher reaction time and less number of wriths when compared to fluoxetine group. Morphine increased, while naloxone, yohimbine and ondansetron decreased the reaction time in a hot plate. In the acetic acid writhing test, a number of wriths significantly decreased when co-treated with morphine and increased when co-treated with naloxone, yohimbine and ondansetron.
\end{abstract}

Conclusion: It is concluded that amitriptyline is a better antinociceptive agent than fluoxetine. Their central and peripheral mechanism of antinociception both involve opioidergic, serotonergic and noradrenergic pathway.

Keywords: Antinociceptive, Amitriptyline, Fluoxetine, Morphine, Naloxone, Yohimbine

(c) 2018 The Authors. Published by Innovare Academic Sciences Pvt Ltd. This is an open access article under the CC BY license (http://creativecommons.org/licenses/by/4.0/) DOI: http://dx.doi.org/10.22159/ijpps.2018v10i11.27706

\section{INTRODUCTION}

Pain is an unpleasant sensory and emotional experience associated with actual or potential tissue damage or described in terms of such damage [1]. In the pain pathway, $\mathrm{A} \delta$ and $\mathrm{C}$ fibres carrying pain terminate in the dorsal horn and excite second order neurons to reach thalamus. From these thalamic areas, the signals are transmitted to basal areas of the brain, as well as to the somatosensory cortex [2]. Endogenous ascending pain modulation occurs at the level of dorsal horn by gate control mechanism. Major components of descending pain control are periaqueductal gray (PAG) and periventricular areas, raphe magnus nucleus (NRM) and pain inhibitory complex located in the dorsal horns of the spinal cord [2].

Several transmitter substances are involved in the analgesia system; especially involved are endogenous opioid peptides (encephalin), serotonin [2] and norepinephrine [3, 4]. The role of opioidergic pathway is well known. Encephalin causes both presynaptic and postsynaptic inhibition of incoming type $\mathrm{C}$ and types $\mathrm{A} \boldsymbol{\delta}$ pain fibers at their synapse in dorsal horn [2]. Regarding the role of serotonin, analgesia produced by spinal injection of serotonin (5-HT) appears to be mediated primarily through 5-HT3 receptors [5]. Pretreatment with tropisetran (5HT3 antagonist) reversed the antinociceptive action of intrathecally administered 5-HT [6]. 5HT3 receptors are implicated in the antinociceptive action of paroxetine (antidepressant of selective serotonin reuptake inhibitor class) as ondansetron (5-HT3 antagonist) inhibited its antinociceptive activity [7]. Regarding the role of the noradrenergic pathway in pain modulation, the noradrenergic pathway from the locus coeruleus also has an inhibitory effect on transmission in the dorsal horn [3]. It was found that $\alpha-2$ play an important role in antidepressant-induced antinociception as RX821002 ( $\alpha-2$ antagonist) could block their antinociceptive action but prazosin ( $\alpha-1$ adrenoceptor antagonist) could not [8]. In the spinal cord, norepinephrine released from descending pathways suppresses pain primarily by acting through $\alpha-2$ receptors [4].

Amitriptyline is a tricyclic antidepressant. fluoxetine is an antidepressant of the selective serotonin reuptake inhibitor (SSRI) class [9]. In the treatment of neuropathic and other pain disorders, antidepressants are being used, but among these which agents are preferable, there is a universal doubt. Studies reveal contradictory and insufficient results. Rani et al., 1996[10] in their study on amitriptyline versus fluoxetine in pain conditions found that fluoxetine was superior. Nisha Michael et al., 2012 [11] in their comparative study between amitriptyline and fluoxetine found amitriptyline to be superior. The mechanism of antinociceptive action of these antidepressant Compounds (amitriptyline and fluoxetine) are not yet known. But the onset of analgesic effect of Tricyclic antidepressants is earlier and it occurs at a lower dose than that is typically required for management of depression [12]. So, in our study, we have done a comparative analysis of the antinociceptive activity of amitriptyline and fluoxetine and evaluated the probable mechanism of this action.

\section{MATERIALS AND METHODS}

\section{Drugs and chemicals}

Amitriptyline was obtained from Himedia Labs, Bangalore. fluoxetine was obtained from Quality Pharma, Dibrugarh. morphine was obtained from Verve healthcare Ltd, Delhi. naloxone was obtained from Neon laboratories Ltd. yohimbine was obtained from himedia Laboratory Pvt. Ltd, Bangalore. ondansetron obtained from Alkem Laboratories Ltd, East Sikkim. Diclofenac Sodium was obtained from 
NOVARTIS co. Pvt. Ltd. Glacial acetic acid was obtained from Qualigens (Fisher scientific).

\section{Dose selection}

Dose of amitriptyline used in this experiment was $20 \mathrm{mg} / \mathrm{kg}[13,14]$, fluoxetine $20 \mathrm{mg} / \mathrm{kg}$ [15], morphine $5 \mathrm{mg} / \mathrm{kg}$ [16], naloxone $3 \mathrm{mg} / \mathrm{kg}$ [17], yohimbine $2 \mathrm{mg} / \mathrm{kg}$ [18], ondansetron $0.1 \mathrm{mg} / \mathrm{kg}$ [7] and diclofenac $5 \mathrm{mg} / \mathrm{kg}$ [19].

\section{Experimental animals}

Healthy male swiss albino mice (25-35 grams) were taken from the Central Animal House, Assam Medical College (registration no. 634/02/a/CPCSEA dated 19/05/02). The animals were housed in standard cages under standard conditions of light and dark cycle and maintained under normal room temperature. The animals were fed with a normal diet and water ad libitum. Before commencing the work permission from the Institutional Animal Ethics Committee was taken and conducted according to CPCSEA guidelines.

\section{Experimental design}

Albino mice (male) weighing 25-35 grams were taken and divided into 11 groups.

Group A-Control (Distilled water),

Group B-Amitriptyline $20 \mathrm{mg} / \mathrm{kg}$,

Group C-Fluoxetine $20 \mathrm{mg} / \mathrm{kg}$,

Group D-Morphine $5 \mathrm{mg} / \mathrm{kg}$

Group E-Amitriptyline $20 \mathrm{mg} / \mathrm{kg}+$ Morphine $5 \mathrm{mg} / \mathrm{kg}$,

Group F-Amitriptyline $20 \mathrm{mg} / \mathrm{kg}+$ Naloxone $3 \mathrm{mg} / \mathrm{kg}$,

Group G-Amitriptyline $20 \mathrm{mg} / \mathrm{kg}+$ Yohimbine $2 \mathrm{mg} / \mathrm{kg}$,

Group H-Amitriptyline $20 \mathrm{mg} / \mathrm{kg}+$ Ondansetron $0.1 \mathrm{mg} / \mathrm{kg}$,

Group I-Fluoxetine $20 \mathrm{mg} / \mathrm{kg}+$ morphine $5 \mathrm{mg} / \mathrm{kg}$,

Group J-Fluoxetine $20 \mathrm{mg} / \mathrm{kg}+$ Naloxone $3 \mathrm{mg} / \mathrm{kg}$,

Group K-Fluoxetine $20 \mathrm{mg} / \mathrm{kg}+$ Yohimbine $2 \mathrm{mg} / \mathrm{kg}$

Group L-Fluoxetine $20 \mathrm{mg} / \mathrm{kg}+$ Ondansetron $0.1 \mathrm{mg} / \mathrm{kg}$.

\section{Central analgesic activity}

The central analgesic activity was tested by Hot Plate method in albino mice. Mice were placed on an aluminum hot plate kept at $55^{\circ} \mathrm{C}[20]$. The reaction time is the time eclipsed between placing the animal on a hot plate to first paw licking (hind paw) or Jumping behavior shown by the animal (whichever appear first) [21]. The Pre-Drug reaction time for each animal was recorded. After that Distilled water and test, drugs were injected intraperitoneally and reaction time was noted at 20,60 and 90 min after drug administration. Cut off time of 15 seconds was taken to avoid thermal injury to the paws of mice [22]. Morphine (5 mg/kg I. P.) was used as a reference standard [16].

\section{Peripheral analgesic activity testing}

The peripheral analgesic activity was tested by glacial acetic acidinduced Writhing test in albino mice. Writhing or stretching syndrome is characterized by a wave of contractions of the abdominal musculature followed by extension of the hind limbs [23].

Distilled water and test drugs were injected intraperitoneally (I. P) 15 min before subjecting the animals to $0.6 \%$ acetic acid I. P. (1 $\mathrm{ml} / 100$ gram) [22]. The number of writhing responses was counted for $20 \mathrm{~min}$. Index of analgesia is referred to as the percentage of protection against abdominal constriction [24]. It is calculated as:

$$
\text { Index of analgesia= }=\frac{\text { No.of writhing in control group-No.of writhing in treated group }}{\text { No of writhing in control group. }}
$$

Diclofenac Sodium (5 mg/kg I. P.) was used as a reference standard [19].

\section{Statistical analysis}

The results were statistically analyzed using one-way ANOVA followed by dunnett's multiple comparison tests and bonferroni's test. Student's t-test (paired) was applied to compare pre-drug reaction time with post-drug reaction time at 20,60 and $90 \mathrm{~min}$ individually. The statistical analysis was done using Graph pad prism software version 5.00. $\mathrm{p}$ values $<0.05$ were considered significant.

\section{RESULTS}

\section{Analgesic activity of amitriptyline and fluoxetine on a hot plate and acetic acid-induced writhing test}

The results are depicted in table 1 . In hot plate method, both amitriptyline and fluoxetine-treated mice showed a significant increase in mean reaction time compared to the control group at 20, 60 and $90 \mathrm{~min}$.

In acetic acid-induced writhing test, with regard to a number of writhing movement, both amitriptyline and fluoxetine-treated animals showed significant protection when compared to control group. Regarding percentage protection, amitriptyline group showed $79 \%$ protection and fluoxetine group showed $63 \%$ protection.

It is seen that amitriptyline is superior to fluoxetine with regard to analgesic activity in both the models both as a central analgesic and as a peripherally acting agent.

Table 1: Analgesic activity of amitriptyline and fluoxetine in hot plate test and acetic acid-induced writhing test

\begin{tabular}{|c|c|c|c|c|c|c|c|}
\hline \multirow{2}{*}{ Group } & \multirow{2}{*}{ Treatment } & \multicolumn{4}{|c|}{ Reaction time in hot plate test (sec) } & \multicolumn{2}{|c|}{ Acetic acid induced writhing test } \\
\hline & & Pre-drug & $20 \mathrm{~min}$ & $60 \mathrm{~min}$ & $90 \mathrm{~min}$ & No of wriths & $\%$ protection \\
\hline A & Control & $4.6 \pm 0.24$ & $4.36 \pm 0.18$ & $3.888 \pm 0.35$ & $4.080 \pm 0.25$ & $59.2 \pm 1.9$ & \\
\hline B & Amitriptyline & $4.582 \pm 0.37$ & $7.528 \pm 0.41 \mathrm{a}, \mathrm{b}$ & $8.266 \pm 0.37 \mathrm{a}, \mathrm{b}$ & $9.502 \pm 0.48 \mathrm{a}, \mathrm{b}$ & $12.4 \pm 0.5 \mathrm{a}$ & $79 \%$ \\
\hline $\mathrm{C}$ & Fluoxetine & $4.226 \pm 0.36$ & $6.524 \pm 0.33 a, b, c$ & $6.496 \pm 0.05 a, b, c$ & $6.432 \pm 0.53 a, b, c$ & $21.6 \pm 1.1 \mathrm{a}, \mathrm{c}$ & $63 \%$ \\
\hline D & Morphine & $4.236 \pm 0.11$ & $7.794 \pm 0.11 \mathrm{a}, \mathrm{b}$ & $9.540 \pm 0.21 \mathrm{a}, \mathrm{b}$ & $10.11 \pm 0.24 \mathrm{a}, \mathrm{b}$ & $10 \pm 0.6 \mathrm{a}$ & $82 \%$ \\
\hline
\end{tabular}

Values are expressed as mean \pm SEM; $(n=5)$. Oneway ANOVA followed by dunnett's multiple comparison test. ANOVA followed by bonferroni's test was done between group B and C. Paired $t$ test was done between pre-drug reaction time versus post drug reaction time at 20,60 and 90 min. a $\mathrm{p}<0.05$ when compared to control group. $\mathrm{b} \mathrm{p}<0.05$ when compared to pre-drug reaction time. $\mathrm{c} p<0.05$ when compared to group $B$.

\section{Analgesic activity of amitriptyline and its combination with morphine, naloxone, yohimbine, and ondansetron in hot plate and acetic acid writhing test}

The results are depicted in table 2 . In central analgesic model, amitriptyline+morphine group showed a statistically significant increase in mean reaction time at 60 and $90 \mathrm{~min}$ when compared to amitriptyline group. Amitriptyline+naloxone, amitriptyline+ yohimbine, and amitriptyline+ondansetron group recorded a significant decrease in mean reaction time was seen at 20,60 and 90 min when compared to amitriptyline group.

In the peripheral analgesic model, amitriptyline+morphine group showed a significant decrease in the number of writhing and an increase in percentage protection while amitriptyline+naloxone, amitriptyline+ yohimbine and amitriptyline+ondansetron group recorded a significant increase in the number of writhing and a decrease in percentage protection when compared to amitriptyline treated group. 
Table 2: Analgesic activity of amitriptyline and its combination with morphine, naloxone, yohimbine and ondansetron in the hot plate and acetic acid writhing test

\begin{tabular}{|c|c|c|c|c|c|c|c|}
\hline \multirow[t]{2}{*}{ Group } & \multirow[t]{2}{*}{ Treatment } & \multicolumn{4}{|c|}{ Reaction time in hot plate (sec) } & \multicolumn{2}{|c|}{ Acetic acid induced writhing test } \\
\hline & & Pre-drug & $20 \mathrm{~min}$ & $60 \mathrm{~min}$ & $90 \mathrm{~min}$ & No of wriths & \% protection \\
\hline B & Amitriptyline & $4.58 \pm 0.37$ & $7.53 \pm 0.41 \mathrm{~b}$ & $8.27 \pm 0.37 b$ & $9.5 \pm 0.48 \mathrm{~b}$ & $12.4 \pm 0.5$ & $79 \%$ \\
\hline $\mathrm{E}$ & $\begin{array}{l}\text { Amitriptyline } \\
+ \text { Morphine }\end{array}$ & $4.4 \pm 0.39$ & $7.99 \pm 0.43 b$ & $\begin{array}{l}13.11 \pm \\
0.62 a, b\end{array}$ & $13.83 \pm 0.65 a, b$ & $0 \mathrm{a}$ & $100 \%$ \\
\hline $\mathrm{F}$ & $\begin{array}{l}\text { Amitriptyline } \\
+ \text { Naloxone }\end{array}$ & $4.8 \pm 0.59$ & $1.77 \pm 0.55 \mathrm{a}, \mathrm{b}$ & $1.044 \pm 0.17 \mathrm{a}, \mathrm{b}$ & $1.3 \pm 0.17 \mathrm{a}, \mathrm{b}$ & $54.2 \pm 1.3 a$ & $8 \%$ \\
\hline G & $\begin{array}{l}\text { Amitriptyline } \\
+ \text { Yohimbine }\end{array}$ & $4.3 \pm 0.53$ & $1.68 \pm 0.44 \mathrm{a}, \mathrm{b}$ & $1.238 \pm 0.22 \mathrm{a}, \mathrm{b}$ & $1.67 \pm 0.40 \mathrm{a}, \mathrm{b}$ & $58 \pm 0.9 \mathrm{a}$ & $2 \%$ \\
\hline $\mathrm{H}$ & $\begin{array}{l}\text { Amitriptyline+ } \\
\text { Ondansetron }\end{array}$ & $4.68 \pm 0.41$ & $2.85 \pm 0.44 a, b$ & $2.998 \pm 0.76 \mathrm{a}, \mathrm{b}$ & $1.09 \pm 0.15 a, b$ & $50.4 \pm 0.9 \mathrm{a}$ & $14 \%$ \\
\hline
\end{tabular}

Values are expressed as mean \pm SEM; $(n=5)$. One-way ANOVA followed by dunnett's test. Paired t-test was done between pre-drug reaction time versus post drug reaction time at 20,60 and 90 min. $a=p<0.05$ when compared to group $B$. $b=p<0.05$ when compared to pre-drug reaction time.

\begin{abstract}
Analgesic activity of fluoxetine and its combinations with morphine, naloxone yohimbine and ondansetron in hot plate and acetic acid writhing test
\end{abstract}

The results are depicted in table 3. In central analgesic model, fluoxetine+morphine group showed a statistically significant increase in mean reaction time at 60 and 90 min when compared to fluoxetine treated group. Fluoxetine+naloxone, fluoxetine+yohimbine and fluoxetine+ondansetron group showed a significant decrease in mean reaction time at 20,60 and 90 min, when compared to fluoxetine, treated group.

In the peripheral analgesic model, the fluoxetine+morphine group showed a significant decrease in the number of writhing and an increase in percentage protection while fluoxetine+naloxone, fluoxetine+yohimbine and fluoxetine+ondansetron group recorded a significant increase in the number of writhing and a decrease in percentage protection when compared to Fluoxetine treated group.

Table 3: Analgesic activity of fluoxetine and its combinations with morphine, naloxone yohimbine and ondansetron in hot plate and acetic acid writhing test

\begin{tabular}{|c|c|c|c|c|c|c|c|}
\hline \multirow[t]{2}{*}{ Group } & \multirow[t]{2}{*}{ Treatment } & \multicolumn{4}{|c|}{ Reaction time in Hotplate (sec) } & \multicolumn{2}{|c|}{ Acetic acid induced writhing test } \\
\hline & & Pre-drug & $20 \min$ & $60 \mathrm{~min}$ & $90 \mathrm{~min}$ & No of wriths & $\%$ protection \\
\hline $\mathrm{C}$ & Fluoxetine & $4.22 \pm 0.35$ & $6.52 \pm 0.33 \mathrm{~b}$ & $6.49 \pm 0.51 \mathrm{~b}$ & $6.4 \pm 0.53 \mathrm{~b}$ & $21.6 \pm 1$ & $63 \%$ \\
\hline I & $\begin{array}{l}\text { Fluoxetine } \\
+ \text { Morphine }\end{array}$ & $4.11 \pm 0.35$ & $7.48 \pm 0.29 b$ & $\begin{array}{l}10.02 \pm \\
0.97 a, b\end{array}$ & $11.92 \pm 0.39 a, b$ & $0 \mathrm{a}$ & $100 \%$ \\
\hline $\mathrm{J}$ & $\begin{array}{l}\text { Fluoxetine } \\
+ \text { Naloxone }\end{array}$ & $4.032 \pm 0.26$ & $\begin{array}{l}1.49 \pm \\
0.31 \mathrm{a}, \mathrm{b}\end{array}$ & $\begin{array}{l}0.88 \pm \\
0.18 \mathrm{a}, \mathrm{b}\end{array}$ & $\begin{array}{l}1.65 \pm \\
0.41 \mathrm{a}, \mathrm{b}\end{array}$ & $\begin{array}{l}54.8 \pm \\
0.86 \mathrm{a}\end{array}$ & $7 \%$ \\
\hline K & $\begin{array}{l}\text { Fluoxetine } \\
+ \text { Yohimbine }\end{array}$ & $4.124 \pm 0.41$ & $\begin{array}{l}2.67 \pm \\
0.76 \mathrm{a}, \mathrm{b}\end{array}$ & $2.62 \pm 0.12 \mathrm{a}, \mathrm{b}$ & $\begin{array}{l}2.92 \pm \\
1.56 \mathrm{a}, \mathrm{b}\end{array}$ & $\begin{array}{l}50 \pm \\
0.70 \mathrm{a}\end{array}$ & $15 \%$ \\
\hline $\mathrm{L}$ & $\begin{array}{l}\text { Fluoxetine+ } \\
\text { Ondansetron }\end{array}$ & $3.838 \pm 0.27$ & $\begin{array}{l}1.17 \pm \\
0.11 \mathrm{a}, \mathrm{b}\end{array}$ & $\begin{array}{l}0.97 \pm \\
0.09 \mathrm{a}, \mathrm{b}\end{array}$ & $\begin{array}{l}0.99 \pm \\
0.22 \mathrm{a}, \mathrm{b}\end{array}$ & $\begin{array}{l}57.4 \pm \\
1.36 \mathrm{a}\end{array}$ & $3 \%$ \\
\hline
\end{tabular}

Values are expressed as mean \pm SEM; $(n=5)$. One-way ANOVA followed by Dunnett's test. Paired t-test was done between pre-drug reaction time versus post-drug reaction time at 20,60 and $90 \mathrm{~min}$. a $\mathrm{p}<0.05$ when compared to group C. b p $<0.05$ when compared to pre-drug reaction time.

\section{DISCUSSION}

In our present study, we found that both amitriptyline and fluoxetine are effective as an analgesic agent in both the central model and peripheral model of analgesic activity.

Regarding central anti-nociceptive action, in our experiment, antinociceptive actions of amitriptyline and fluoxetine were synergized by morphine, and it was antagonized by naloxone (opioid receptor antagonist), yohimbine ( $\alpha-2$ antagonist) and ondansetron (5-HT3receptor antagonist) in hot plate method. Thus, it seems that their central analgesic action involves opioidergic, serotonergic and noradrenergic pathways. Fluoxetine and amitriptyline are reported to increase the density of opioid receptors [25-27]. They also cause the release of endogenous opioid peptides [27]. Acetorphan (encephalinase inhibitor) potentiated the antinociceptive activity of antidepressants indicating a clear role of opioidergic system in antidepra essant-induced nociception [28]. These drugs are also reported to act directly on opioid receptors [29]. Antidepressants can displace opioids from binding sites in radioligand binding assays [30]. For their opioidergic action, fluoxetine may be acting through $\mu$ $[31,32]$ opioid receptor. Amitriptyline seems to be acting through $\mu$ $[28], \kappa[29$ th] and $\delta[28,29]$ opioid receptors. Regarding the involvement of serotonergic and noradrenergic pathway, NE and 5-HT may activate pain inhibitory interneurons in the superficial layers of dorsal horn [33]. 5-HT facilitates the release of beta-endorphin [34]. Antidepressants which increase the availability of NE and 5HT leads to enhancement of opioid pathways [35]. The opioid peptides also modulate Locus Coeruleus (LC). Activation of presynaptic delta-opioid receptors inhibits GABA release and thus excites spinally projecting noradrenergic LC neurons [36]. Alpha-2 adrenoceptors modulate pain in many ways. They may cause presynaptic inhibition (at the level of primary afferent nociceptors), inhibition of pain-relaying spinothalamic neurons (postsynaptic inhibition). Alpha-2 Cadrenoceptors present on excitatory interneurons in the dorsal horn of spinal cord contributes to spinal control of pain [4].

Coming to peripheral antinociceptive action, anti-nociceptive actions of amitriptyline and fluoxetine were synergized by morphine and antagonized by naloxone, yohimbine, and ondansetron in the peripheral analgesic model (acetic acid-induced writhing test). Thus, it can be said that their peripheral analgesic action also involves opioidergic, noradrenergic and serotonergic mechanisms. A prostaglandin synthesis inhibitory action may also be present. Regarding the involvement of opioidergic system in the peripheral antinociceptive action, it is a known fact that immune cells contain numerous opioid peptides but the predominant opioid peptides involved in immune-cell mediated antinociception are thought to be endorphin and encephalin [37]. Endogenous opioid peptides are released by immune cells to reduce inflammatory pain. noradrenaline, corticotropin-releasing factor (CRF) and interleukin$1 \alpha$ stimulate immune cells to secrete their opioid peptides [37]. These opioid peptides cause inhibition of pro-inflammatory neuropeptide release and sensory neuron excitability [38]. Opioid 
mimicking or enhancing a property of the antidepressants may also play a role in their peripheral analgesic action [30]. Regarding the involvement of serotonergic pathway in the peripheral antinociceptive action, in our study, in the peripheral analgesic model, 5-HT3 antagonist ondansetron antagonized the antinociceptive action of both amitriptyline and fluoxetine in the acetic acid writhing model. Similar observation was also made by Kesim M et al., 2005 [7] with paroxetine. But the exact mechanism of how peripheral 5-HT3 modulation is involved in the peripheral antinociceptive action of both the drugs is still not clear. Pain sensation in acetic acid induced writhing method is due to prostaglandin biosynthesis (Via cyclooxygenase pathway) triggered by localized inflammatory reaction $[39,40]$. So, agents which reduce the number of writhing will render their effect preferably by inhibition of prostaglandin biosynthesis $[39,40]$. In our study, both the antidepressants were effective in preventing acetic acid-induced writhing movements in mice. So, a prostaglandin synthesis inhibitory action of the drugs (amitriptyline and fluoxetine) also may be present and which may be responsible in part for their peripheral antinociceptive action. This needs further investigation.

\section{CONCLUSION}

In this study, it was found that both amitriptyline and fluoxetine has antinociceptive property and amitriptyline is a better antinociceptive agent than fluoxetine. Their mechanism of central antinociceptive action may involve opioidergic actions, serotonin reuptake inhibitory action, and norepinephrine reuptake inhibitor property of both the drugs. A complex interaction of all the three systems may be playing the main role.

Regarding peripheral antinociceptive action, it has been observed that their interaction with opioidergic system and noradrenaline mediated enhancement of peripheral opioidergic system seems to play the main role. Additional 5-HT3 receptor-mediated or prostaglandin synthesis inhibitory action may also be involved in their peripheral analgesic action. Again, antidepressants are known to interact with many other receptor systems. So, some of these systems may also take part in their analgesic action. This needs further investigation.

\section{AUTHORS CONTRIBUTIONS}

Both the authors contributed equally in protocol preparation, ethical approval, the conduct of the experiment, data collection, analysis, and manuscript preparation.

\section{CONFLICT OF INTERESTS}

Nil

\section{REFERENCES}

1. IASP taxonomy. Pain terms.[Internet]. Washington DC: International Association for the study of pain; 2013. Available from: http://www.iasppain.org/Content/NavigationMenu/ GeneralResourceLinks/PainDefinitions/defaulthtm.[Last accessed on 10 Sep 2013]

2. Guyton AC, Hall JE. eds. Somatic Sensations: II. Pain, Headache, and Thermal Sensations. Textbook of medical Physiology. 11th ed. Noida: Elsevier Saunders; 2008. p. 598-609.

3. Rang HP, Dale MM, Ritter JM, Flower RJ. editors. Analgesic Drugs. Rang and Dale's Pharmacology. $6^{\text {th }}$ ed. China: Churchill livingstone; 2009. p. 588-609.

4. Pertovaara A. Noradrenergic pain modulation. Prog Neurobiol 2006;80:53-83.

5. Paul D, Yao D, Zhu P, Minor LD. 5-hydroxytryptamine 3 (5-HT3) receptors mediate spinal 5-HT antinociception: an antisense approach. J Pharmacol Exp Ther 2001;298:674-8.

6. Bardin L, Lavarenne J, Eschalier A. Serotonin receptor subtypes involved in the spinal antinociceptive effect of 5-HT in rats. Pain 2000;86:11-8.

7. Kesim M, Duman EN, Kadioglu M. The different roles of 5-HT2, and 5-HT3 receptors on the antinociceptive effect of paroxetine in chemical stimuli in mice. J Pharmacol Sci 2005;97:61-6.

8. Gray AM, Pache DM, Sewel RD. Do alpha2-adrenoreceptors play an integral role in the antinociceptive mechanism of action of antidepressant compounds. Eur J Pharmacol 1999;378:161-8.

9. Schreiber S, Pick CG. From selective to highly selective SSRIs; a comparision of the antinociceptive properties of Fluoxetine, Fluvoxamine, Citalopram and Escitalpram. Eur Neuropsychopharmacol 2006;16:464-8.

10. Rani PU, Naidu MU, Prasad VB. An evaluation of antidepressants in rheumatic pain conditions. Anaesth Anal 1996;83:371-5.

11. Michael N, Bharti Chogtu B, Eesha BR. Comparing the antinociceptive effects of Amitriptiline and Fluoxetine in rats. Indian J Pharmacol 2011;43 Suppl:128-9.

12. Rathmell JP, Fields HL. Pain: pathophysiology and management. In: LongoHarrison's principles of Internal Medicine. Fauci AS, Kasper DL, Hauser SL, Jameson JL, Loscalzo J. editors. Harrison's principles of Internal Medicine. 18th ed. New Delhi: McGrawHill; 2012. p. 93-101.

13. Paudel KR, Das BP, Rauniar GP. Antinociceptive effect of amitrptyline in mice in acute pain models. Indian J Exp Biol 2007;45:529-31.

14. Ghelardini C, Galeotti N, Bartolini A. Antinociception induced by Amitriptyline and Imipramine is mediated by alpha-2Aadrenoceptors. Japan J Pharmacol 2000;82:130-7.

15. Singh VP, Jain NK, Kulkarni SK. On the antinociceptive effect of Fluoxetine, a selective serotonin reuptake inhibitor. Brain Res 2001;915:218-26.

16. Sureshkumar S, Sivakumar T, Chandrasekhar MJN Investigating the anti-inflammatory and analgesic effect of leaves of wedelia chinensis (osbeck) Merr. In standard experimental animal. Iran J Pharm Res 2006;2:123-9.

17. Sounvoravong S, Nakashima MN, Wada M. Modification of the antiallodynic and antinociceptive effects of morphine by the peripheral and central action of fluoxetine in a neuropathic mice model. Acta Biol Hung 2007;58:369-79.

18. Morales L, Perez Garcia C, Alguacil LF. Effects of yohimbine on the antinociceptive and place conditioning effects of the opioid agonist in rodents. Br J Pharmacol 2001;133:172-8.

19. Ghule RS, Venkatanarayanan SR, Thakre SP. Analgesic activity of Cuscutacampestris Yuncker a parasitic plant grown on neriumindicum mill. J Adv Pharm Educ Res 2011;1:45-51.

20. Tiwari A, Singh A. Synthesis and antinociceptive activity of novel mannich base derivatives of some new fused 3,5pyrazolidinedione. J Adv Pharm Technol Res 2014;5:41-7.

21. Kulkarni SK. Practical pharmacology and clinical pharmacy. 1st ed. Delhi; Vallabh Prakasan; 2009.

22. Medhi B, Prakash A. Practical manual of experimental and clinical pharmacology. 1st ed. New delhi; Jaypee brothers medical publishers pvt. Ltd; 2010.

23. Ghosh MN. Fundamentals of experimental pharmacology. 5th ed. Kolkata: Hilton and Company; 2011.

24. Singh H, Banerjee S, Karan S, Chatterjee TK. Antinociceptive activity of Freeze dried powdered morinda citrifolia L. fruit. Int J Pharm Pharm Sci 2013;5:608-11.

25. Churruca I, Portillo MP, Zumalabe JM. Fluoxetine alters mu opioid receptor expression in obese Zucker rat extrahypothalamic regions. Int J Neurosci 2006;116:289-98.

26. Tocque B, Albouz S, Boutry JM. Desipramine elicits the expression of opiate receptors and sulfogalactosylceramide synthesis in rat C6 glioma cells. J Neurochem 1984;42:1101-6.

27. Hamon M, Gozlan H, Bourgoin S. Opioid receptors and neuropeptides in the CNS in rats treated chronically with Amoxapine or Amitriptyline. Neuropharmacol 1987;26:531-9.

28. Gray AM, Spancer PSJ, Sewell RDE. The involvement of the opioidergic system in the antinociceptive mechanism of action of antidepressant compounds. Br J Pharmacol 1998;124:66974.

29. Onali P, Dedoni S, Olianas MC. Direct agonistic activity of tricyclic antidepressants at distinct opioid receptor subtypes. J Pharmacol Exp Ther 2010;332:255-65.

30. Sawynok J, Essar MJ, Reid AR. Antidepressants as analgesics: an overview of central and peripheral mechanisms of action. J Psychiatry Neurosci 2001;26:21-9. 
31. Kurlekar PN, Bhatt JD. Study of the antinociceptive activity of fluoxetine and its interaction with morphine and naloxone in mice. Ind J Pharmacol 2004;36:369-72.

32. Sikka P, Kaushik S, Kumar G. Study of antinociceptive activity of SSRIs (fluoxetine and escitaopram) and atypical antidepressants (Venlafaxine and Mirtazepine) and their interaction with morphine and Naloxone in mice. J Pharm Bioallied Sci 2011;3:412-6.

33. Cui M, Feng Y, McAdoo DJ. Periaqueductal grey matter stimulation-induced inhibition of nociceptive dorsal horn neurons in rats is associated with the release of norepinephrine, serotonin, and amino acids. J Pharmacol Exp Ther 1999;289:868-76.

34. Zangen A, Nakash R, Yadid G. Serotonin-mediated increases in the extracellular levels of beta-endorphin in the arcuate nucleus and nucleus accumbens: a microdialysis study. J Neurochem 1999;73:2569-74.
35. Berrocoso E, Sanchez-Blazquez P, Garzon J. Opiates as antidepressants. Curr Pharm Des 2009;15:1612-22.

36. Pran YZ, Li DP, Chen SR. Activation of delta opioid receptor excites spinally projecting Locus ceruleus neurons through inhibiting GABAergic inputs. J Neurophysiol 2002;88:2675-83.

37. Kapitzke D, Vetter I, Cabot PJ. Endogenous opioid analgesia in peripheral tissues and the clinical implications for pain control. Ther Clin Risk Manag 2005;1:279-97.

38. Stein C, Lang LJ. Peripheral mechanisms of opioid analgesia. Curr Opinion Pharmacol Neurosci 2009;9:3-8.

39. Konate K, Zerbo P, Ouedraogo M. Antinociceptive properties in rodents and the possibility of using polyphenol-rich fractions from sidaurens L. (Malvaceae) against of dental caries bacteria. Ann Clin Microbiol Antimicrob 2013;12:4.

40. Salwe K, Mirunalini R, Mano J, Manimekalai K. Evaluation of analgesic activity of murraya koenigii and coriandrum sativum leaves extract in animal model. Asian J Pharm Clin Res 2018;11:328-31. 